\title{
PEMODELAN KARAKTERISTIK PENYERAPAN AIR PADA JAGUNG (Zea mays L.), SORGUM (Sorghum bicolor L.), DAN HANJELI (Coix lacyma-jobi L.) SELAMA PERENDAMAN
}

\section{MODELLING THE WATER ABSORPTION CHARACTERISTICS OF CORN (Zea mays L.), SORGHUM (Sorghum bicolor L.), AND HANJELI (Coix lacyma-jobi L.) DURING SOAKING}

\author{
Dwi Dian Novita ${ }^{1}$, Asropi ${ }^{2}$, Sapto Kuncoro ${ }^{1}$, dan Winda Rahmawati ${ }^{1}$ \\ ${ }^{1}$ Jurusan Teknik Pertanian, Fakultas Pertanian, Universitas Lampung, \\ JI. S. Brojonegoro No. 1 Gedong Meneng, Bandar Lampung. 35145 \\ ${ }^{2}$ Balai Pengkajian Teknologi Pertanian (BPTP) Lampung, \\ JI. ZA. Pagar Alam No. 1a Rajabasa, Bandar Lampung. 35144 \\ *Correspondence: rofianwar4@gmail.com
}

\begin{abstract}
Abstrak
Karakteristik penyerapan air dari biji jagung, sorgum, dan hanjeli selama perendaman dipelajari pada dua jenis larutan yaitu $\mathrm{pH}$ netral dan alkali, serta pada tiga suhu yang berbeda yaitu 30,45 , dan $60^{\circ} \mathrm{C}$. Persamaan Peleg digunakan untuk mengetahui laju penyerapan air dan kapasitas penyerapan air maksimum serta untuk menentukan kadar air kesetimbangan. Kinetika adsorpsi mengikuti Hukum Difusi Fick. Nilai koefisien difusi meningkat karena peningkatan suhu dan jenis larutan perendaman. Hasil perhitungan nilai koefisien difusi berkisar $1,61-1,82 \times 10^{-11} \mathrm{~m}^{2} \mathrm{~s}^{-1}$ untuk sorgum; $1,97-2,64 \times 10^{-11} \mathrm{~m}^{2} \mathrm{~s}^{-1}$ untuk hanjeli; dan $4,80-5,66 \times 10^{-11} \mathrm{~m}^{2} \mathrm{~s}^{-1}$ untuk jagung. Perendaman pada larutan alkali menghasilkan nilai energi aktivasi yang lebih kecil. Persamaan Arrhenius dapat digunakan dengan baik dalam pendugaan nilai koefisien difusi berdasarkan nilai energi aktivasi dan suhu perendaman.

Kata kunci: difusi, hanjeli, jagung, perendaman, sorgum.
\end{abstract}

\begin{abstract}
The water absorption characteristics of corn kernels, sorghum, and job's tears during soaking were studied in two types of solutions namely neutral and alkaline $\mathrm{pH}$, on three different temperatures 30,45 , and $60{ }^{\circ} \mathrm{C}$. The Peleg equation was used to determine the water absorption rate and maximum water absorption capacity and to determine the water content equilibrium. The absorption kinetics follows Fick's diffusion law. The diffusion coefficient value increased because of temperature increased and solution type. The Analyses results of the diffusion coefficient range from $1.61-1.82 \times 10-11 \mathrm{~m}^{2} \mathrm{~s}^{-1}$ for sorghum; $1.97-2.64 \times 10-11 \mathrm{~m}^{2} \mathrm{~s}^{-1}$ for job's tears; and $4.80-5.66 \times 10-11 \mathrm{~m}^{2} \mathrm{~s}^{-1}$ for corn. Soaking in an alkaline solution results a smaller activation energy value. The Arrhenius equation could be used well in estimating diffusion coefficient values based on the activation energy value and the soaking temperature.

Keywords: diffusion, job's tears, corn, soaking, sorghum.
\end{abstract}

\section{PENDAHULUAN}

Konsumsi beras di Indonesia semakin meningkat seiring dengan pertumbuhan jumlah penduduk. Meskipun pemerintah dalam beberapa tahun terakhir telah berhasil meningkatkan produksi beras, namun dengan kondisi 95\% penduduk mengutamakan beras sebagai makanan pokok sehingga tingkat konsumsi beras nasional sebesar $1,57 \mathrm{~kg} / \mathrm{kapita} /$ minggu (BPS, 2017), serta ancaman perubahan iklim global, tetap menjadi permasalahan utama dalam penyediaan beras sebagai bahan pangan utama.
Selain beras, tanaman serealia yang dapat dimanfaatkan sebagai sumber pangan meliputi jagung, sorgum, hanjeli (jali-jali), jawawut (milet), dan gandum. Jagung dan sorgum merupakan bahan pangan pendamping beras yang mempunyai keunggulan komparatif terhadap serealia lain seperti gandum maupun beras. Pemanfaatan hanjeli sebagai bahan pangan juga masih kurang dikenal masyarakat, walaupun kandungan gizi dasarnya relatif lebih tinggi dibanding sorgum (Grubben \& Partohardjono,1996). 
Pengolahan serealia seperti pada biji jagung, sorgum, dan hanjeli sering mengharuskan bijian tersebut direndam terlebih dahulu untuk memudahkan pengolahan selanjutnya seperti penggilingan, atau memasak. Penyerapan air dalam proses perendaman biji-bijian dipengaruhi oleh kadar air awal, jenis bijian, lama perendaman, suhu dan keasaman air (Karapantsios, Sakonidou, \& Raphaelides, 2002). Meningkatkan suhu perendaman adalah cara paling efektif untuk mempercepat penyerapan air sehingga mempersingkat waktu perendaman pada biji sorgum (Silva, Jorge, \& Jorge, 2018), biji jagung (Agarry, Afolabi \& Tunde-Akintunde, 2014), dan biji padi (Ganguli \& Ghosh, 2014).

Pemodelan proses penyerapan air pada jagung, sorgum dan hanjeli membantu kita memahami dinamika dan kinetika dalam perendaman sehingga dapat menjadi pertimbangan dalam menentukan prosedur pengolahan yang tepat bagi biji-bijian tersebut. Dengan demikian, model penyerapan air ke dalam bahan ini sangat penting secara teoritis dan praktis bagi industri pengolahan. Sejumlah persamaan telah banyak digunakan untuk menggambarkan karakteristik penyerapan air dari bahan makanan. Sebagian besar analisis didasarkan pada Hukum Fick tentang difusi. Sedangkan Persamaan Peleg (Peleg, 1988) digunakan untuk mengetahui laju penyerapan air dan kapasitas penyerapan air maksimum dalam bahan makanan terutama sereal basah dan butiran makanan polongan secara akurat. Penelitian ini bertujuan untuk mengetahui pengaruh suhu dan $\mathrm{pH}$ larutan terhadap karakteristik penyerapan air pada jagung, sorgum, dan hanjeli selama perendaman.

\section{Bahan dan Alat}

\section{METODE}

Bahan yang digunakan adalah biji sorgum merah dan jagung pulut yang berasal dari Balitsereal Maros serta hanjeli yang diperoleh dari petani di Sumedang. Alat yang digunakan adalah waterbath (Selecta Digiterm 200), oven (MMM Venticell), timbangan digital (Henherr BL-
$\mathrm{H} 2$ ), tabung reaksi $45 \mathrm{~mL}$, stop watch, cawan alumunium, dan desikator.

\section{Prosedur Penelitian}

Bahan yang digunakan terlebih dahulu dilakukan proses sortasi dan penyeragaman ukuran yang selanjutnya dikeringkan hingga kadar air $10-12 \%$ bk. Sebanyak 7 gram biji sorgum (S), hanjeli $(\mathrm{H})$, dan jagung $(\mathrm{J})$ untuk setiap sampel dilakukan perendaman ke dalam tabung reaksi yang telah terisi larutan perendaman $\mathrm{pH}$ netral $(\mathrm{N})$ dan larutan alkali 0,5\% $\mathrm{NaHCO}_{3}$ (A) dengan perbandingan 1:5 berat per volume larutan. Proses perendaman dilakukan selama 24 jam pada tiga tingkat suhu $\left(30,45,60^{\circ} \mathrm{C}\right)$ dan dilakukan pengukuran kadar air (metode gravimetri dalam \% bk) dengan interval waktu tertentu selama perendaman.

\section{Pemodelan Penyerapan Air}

Laju penyerapan air dan kapasitas penyerapan air maksimum selama perendaman dianalisa menggunakan Persamaan Peleg sebagai berikut:

$$
\mathrm{M}_{(\mathrm{t})}=\mathrm{M}_{0}+\frac{t}{k_{1}+k_{2} t}
$$

Nilai konstanta $k_{1}$ dan $k_{2}$ diperoleh dari persamaan linier :

$$
\frac{t}{\mathrm{M}_{\mathrm{t}}-\mathrm{M}_{0}}=k_{1}+k_{2} t
$$

dimana $\mathrm{M}_{\mathrm{t}}$ adalah kadar air pada waktu $\mathrm{t}$ (\% bk), $\mathrm{M}_{0}$ adalah kadar air awal (\% bk), $\mathrm{t}$ adalah waktu perendaman (menit), $k_{1}$ adalah nilai konstanta Peleg (menit $\%^{-1}$ ), dan $k_{2}$ adalah konstanta kapasitas Peleg $\left(\%^{-1}\right)$.

Pada proses perendaman yang lama $(\mathrm{t} \rightarrow \infty)$, kadar air kesetimbangan $\left(\mathrm{M}_{\mathrm{e}}\right)$ berkorelasi dengan konstanta kapasitas Peleg $\left(k_{2}\right)$ dengan persamaan :

$$
\mathrm{M}_{\mathrm{e}}=\mathrm{M}_{0}+\frac{1}{k_{2}}
$$

Proses difusi air ke dalam biji-bijian terutama disebabkan oleh gradien konsentrasi. Gradien ini cenderung merubah molekul air untuk menyamakan konsentrasi. Nilai koefisien difusi air dihitung menggunakan Persamaan Crank (Crank, 1975), dengan kondisi batas: (a) koefisien difusi efektif tidak tergantung pada konsentrasi uap air, (b) volume bahan tidak berubah selama penyerapan 
air, dan (c) permukaan bahan mencapai kadar air kesetimbangan secara cepat. Pendugaan nilai koefisien difusi pada benda bulat menggunakan persamaan berikut:

$\frac{\mathrm{M}_{\mathrm{t}}-\mathrm{M}_{\mathrm{e}}}{\mathrm{M}_{0}-\mathrm{M}_{\mathrm{e}}}=\frac{6}{\pi^{2}} \sum_{n=1}^{\mathrm{m}} \frac{1}{n^{2}} \exp \left(\frac{-n^{2} \pi^{2} \text { Deff } t}{r^{2}}\right)$

Persamaan (4) dapat diselesaikan untuk mendapatkan nilai koefisien difusi (Deff) dengan persamaan berikut :

Deff $=\frac{K r^{2}}{\pi^{2}}$

dimana Deff adalah koefisien difusi $\left(\mathrm{m}^{2}\right.$ detik $\left.^{-1}\right), K$ adalah koefisien pembasahan $\left(\right.$ detik $\left.^{-1}\right)$, dan $r$ adalah jari-jari bahan (m).

Hubungan koefisien difusi dan suhu mutlak berkorelasi dalam Persamaan Arrhenius sebagai berikut:

Deff $=$ Do exp $\frac{E a}{R T}$

dengan Do adalah konstanta laju (tidak bergantung pada suhu), Ea adalah energi aktivasi $(\mathrm{J} / \mathrm{mol}), R$ adalah konstanta gas $(8,314 \mathrm{~J} / \mathrm{mol} \mathrm{K})$, dan $\mathrm{T}$ adalah suhu mutlak (K). Ploting nilai In Deff terhadap (1/T) akan dihasilkan slope sebagai nilai Ea/R.

\section{HASIL DAN PEMBAHASAN}

\section{Kinetika Penyerapan Air}

Hasil pengamatan menunjukkan perilaku penyerapan air yang khas. Kadar air biji sorgum (Gambar 1a dan 1b), hanjeli (Gambar 1c dan 1d), jagung (Gambar 1e dan 1f) selama proses perendaman menunjukkan tingkat penyerapan air yang cepat diawal perendaman dan kemudian mendekati kondisi kesetimbangan (Me). Tingkat penyerapan awal yang tinggi diduga terjadi karena efek kapilaritas yang terjadi pada pori-pori dan retakan biji-bijian sehingga mempercepat laju penyerapan air ke dalam biji-bijian (Kashiri, Kashaninejad, \& Aghajani, 2010).

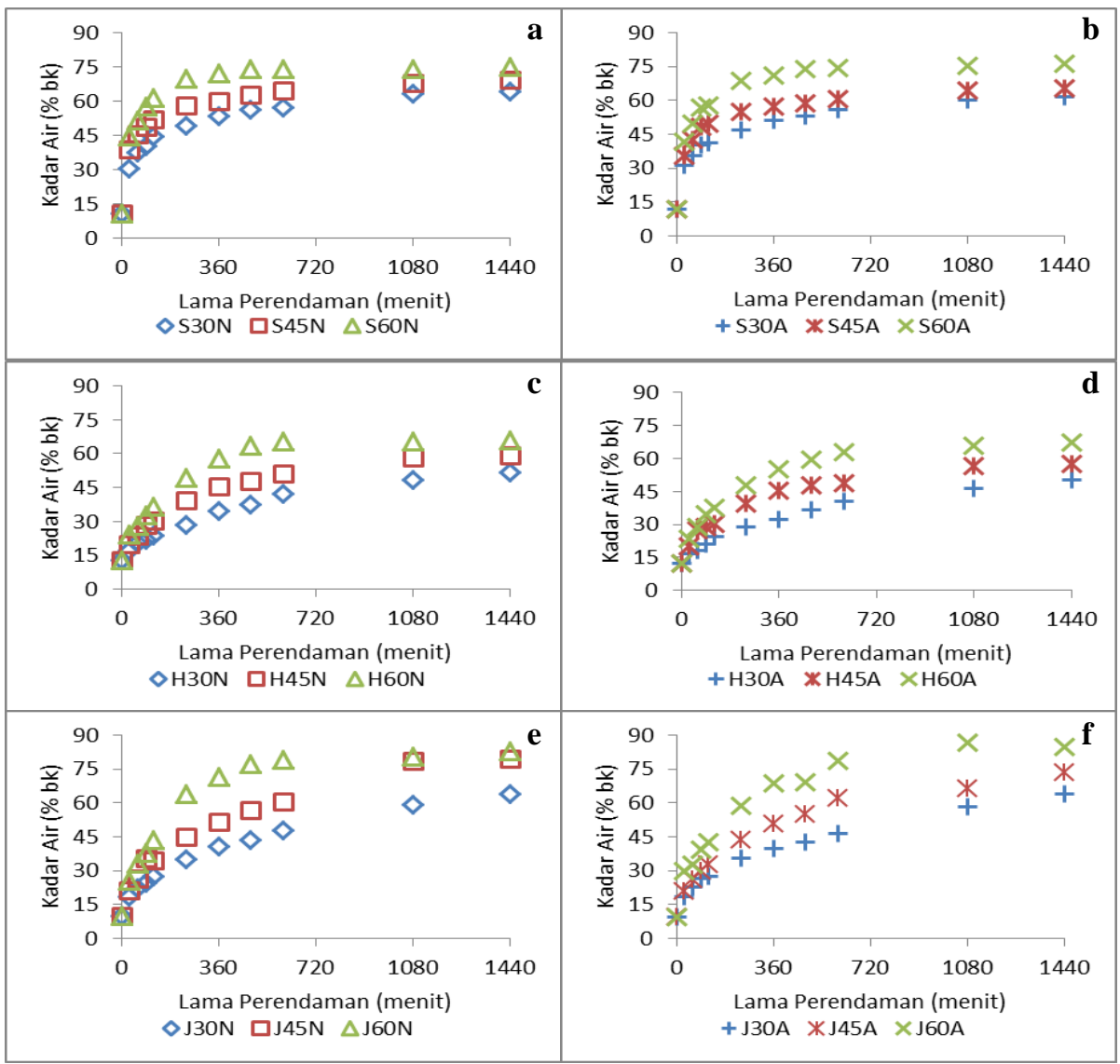

Gambar 1. Perubahan kadar air biji sorgum dalam perendaman larutan $\mathrm{pH}$ netral (a) dan alkali (b), biji hanjeli dalam larutan $\mathrm{pH}$ netral (c) dan alkali (d), serta biji jagung dalam larutan $\mathrm{pH}$ netral (e) dan alkali (f) 
Tingkat penyerapan air diawal perendaman juga dipengaruhi oleh suhu perendaman yang lebih tinggi (Karapantsios, Sakonidou, \& Raphaelides, 2002). Pada suhu yang tinggi, biji-bijian akan mengalami kerusakan (denaturasi) sehingga bijian akan cepat lunak dan poripori biji akan membesar. Proses penyerapan air yang lebih cepat diawal perendaman menyebabkan kejenuhan pada pori-pori biji lebih cepat sehingga akan mengurangi efek kapilaritas karena konsentrasi air dalam biji-bijian meningkat. Dalam kondisi tersebut, maka kadar air kesetimbangan biji-bijian dalam perendaman suhu yang lebih tinggi lebih cepat diperoleh dibandingkan suhu yang lebih rendah. Pengaruh suhu dalam proses penyerapan air selama perendaman juga telah dilaporkan oleh Addo \& Bart-Plange, (2009); Addo, BartPlange, \& Dzisi, (2006); Tagawa et al., (2003); dan Seyhan-Gurtas \& Evranuz, (2001).

Dari Gambar 1 diketahui bahwa perendaman biji hanjeli memiliki rasio peningkatan kadar air rata-rata terkecil sebesar 77,73 dan $79,07 \%$ dibandingkan dengan perendaman biji sorgum dan jagung yang memiliki rasio peningkatan kadar air rata-rata 84,46 dan $82,42 \%$; serta 86,70 dan $87,02 \%$ pada perendaman $\mathrm{pH}$ netral dan alkali. Tingginya rasio penyerapan air pada sorgum dan jagung dibandingkan pada biji hanjeli disebabkan karena biji sorgum dan jagung memiliki kandungan pati yang lebih tinggi dibandingkan pada biji hanjeli (Grubben \& Partohardjono,1996).

\section{Model Penyerapan Air}

Persamaan Peleg merupakan persamaan non eksponensial yang dapat menggambarkan laju penyerapan massa air $\left(k_{1}\right)$ dan kapasitas penyerapan massa maksimum $\left(k_{2}\right)$. Persamaan linear yang diperoleh menunjukkan nilai $k_{1}$ dan $k_{2}$ masing-masing perlakuan suhu dan nilai kadar air kesetimbangan $\left(M_{e}\right)$ ditunjukkan dalam Tabel 1. Nilai koefisien determinasi yang bervariasi dari 0,936 sampai 0,999 menunjukkan Persamaan Peleg dapat digunakan dengan baik dalam menggambarkan perilaku penyerapan air biji sorgum, hanjeli, dan jagung selama proses perendaman.

Tabel 1. Nilai $k_{1}$ dan $k_{2}$ dalam persamaan Peleg dan nilai kadar air kesetimbangan (Me)

\begin{tabular}{|c|c|c|c|c|c|c|}
\hline$B i j i$ & & Suhu & $\begin{array}{c}\boldsymbol{k}_{\boldsymbol{1}} \\
\left(10^{-2} \text { detik } \%^{-1}\right)\end{array}$ & $\begin{array}{c}\boldsymbol{k}_{\mathbf{2}} \\
\left(10^{-2} \%^{-1}\right)\end{array}$ & $\mathbf{R}^{2}$ & $\mathbf{M}_{\mathbf{e}}(\% \mathrm{bk})$ \\
\hline \multirow{6}{*}{ Sorgum } & \multirow{3}{*}{$\begin{array}{c}\mathrm{pH} \\
\text { netral }\end{array}$} & 30 & 129,95 & 1,82 & 0,995 & 65,68 \\
\hline & & 45 & 78,44 & 1,68 & 0,998 & 70,26 \\
\hline & & 60 & 37,71 & 1,53 & 0,999 & 76,10 \\
\hline & \multirow{3}{*}{ Alkali } & 30 & 146,51 & 1,95 & 0,994 & 63,10 \\
\hline & & 45 & 90,11 & 1,83 & 0,997 & 66,46 \\
\hline & & 60 & 53,30 & 1,52 & 0,999 & 77,61 \\
\hline \multirow{6}{*}{ Hanjeli } & \multirow{3}{*}{$\begin{array}{c}\mathrm{pH} \\
\text { netral }\end{array}$} & 30 & 704,12 & 2,21 & 0,936 & 58,22 \\
\hline & & 45 & 366,22 & 1,94 & 0,979 & 64,52 \\
\hline & & 60 & 203,32 & 1,72 & 0,986 & 71,11 \\
\hline & \multirow{3}{*}{ Alkali } & 30 & 675,16 & 2,29 & 0,943 & 55,72 \\
\hline & & 45 & 309,39 & 2,03 & 0,984 & 61,31 \\
\hline & & 60 & 205,68 & 1,67 & 0,991 & 71,93 \\
\hline \multirow{6}{*}{ Jagung } & \multirow{3}{*}{$\begin{array}{c}\mathrm{pH} \\
\text { netral }\end{array}$} & 30 & 411,61 & 1,68 & 0,950 & 69,42 \\
\hline & & 45 & 273,83 & 1,30 & 0,960 & 86,82 \\
\hline & & 60 & 137,58 & 1,27 & 0,991 & 88,64 \\
\hline & \multirow{3}{*}{ Alkali } & 30 & 393,10 & 1,71 & 0,946 & 67,96 \\
\hline & & 45 & 266,49 & 1,46 & 0,976 & 77,97 \\
\hline & & 60 & 153,43 & 1,21 & 0,987 & 92,12 \\
\hline
\end{tabular}


Secara umum nilai $k_{1}$ dan $k_{2}$ mengalami penurunan seiring dengan peningkatan suhu perlakuan. Semakin rendah nilai $k_{1}$ menunjukkan proses penyerapan air awal semakin tinggi dan perubahan nilai $k_{1}$ adalah indikasi pengaruh meningkatnya suhu dalam laju penyerapan air (Tunde-Akintunde, 2010). Sedangkan penurunan nilai $k_{2}$ terhadap peningkatan suhu menunjukkan kapasitas penyerapan air oleh bijian akan semakin tinggi. Dari Tabel 1 juga diketahui kombinasi perlakuan larutan perendaman alkali dan suhu tinggi menyebabkan peningkatan nilai kapasitas penyerapan air maksimum pada ketiga jenis serealia di atas, meskipun tidak diiringi oleh peningkatan laju penyerapan air. Hal ini sejalan dengan yang dilaporkan Bello, Tolaba \& Suarez (2004) yang menyatakan tingkat penyerapan air oleh bijian dalam larutan alkali lebih tinggi selama proses perendaman.

\section{Koefisien Laju Pembasahan dan Koefisien Difusi \\ Koefisien pembasahan (K) merupakan laju air yang terserap oleh}

bahan dalam satuan waktu. Semakin besar nilai koefisien pembasahan menunjukkan bahwa proses penyerapan air oleh bahan berlangsung semakin cepat. Nilai koefisien ini diperoleh dari model Persamaan Newton yang merupakan persamaan eksponensial dengan cara memplotkan nilai rasio kadar air (MR) dengan waktu perendaman sehingga akan diperoleh grafik laju pembasahan.

Dari Tabel 2 dapat diketahui bahwa peningkatan suhu perendaman akan diikuti oleh peningkatan nilai koefisien laju pembasahan. Perendaman pada larutan alkali juga menyebabkan peningkatan nilai koefisien laju pembasahan pada biji hanjeli dan jagung, namun tidak terjadi pada perendaman biji sorgum. Hal tersebut diduga proses difusi terhambat oleh tanin yang terlarut dan menempel pada permukaan biji sorgum sehingga laju pembasahan menjadi lebih lambat (Asropi, Bintoro, Karyadi, Rahayoe, \& Saputro, 2019). Perbedaan nilai koefisien laju pembasahan juga dapat disebabkan perbedaan dalam komposisi fisikokimia dari setiap bijian.

Tabel 2. Nilai koefisien laju pembasahan ( $K$ ) dan koefisien difusi (Deff)

\begin{tabular}{|c|c|c|c|c|c|}
\hline$B i j i$ & Larutan & Suhu & $\boldsymbol{K}\left(10^{-3}\right.$ menit $\left.^{-1}\right)$ & $\mathbf{R}^{2}$ & $\operatorname{Deff}\left(10^{-12} \mathrm{~m}^{2} \mathrm{~s}^{-1}\right)$ \\
\hline \multirow{6}{*}{ Sorgum } & \multirow{3}{*}{$\begin{array}{c}\mathrm{pH} \\
\text { netral }\end{array}$} & 30 & 2,26 & 0,96 & 16,35 \\
\hline & & 45 & 2,44 & 0,94 & 17,65 \\
\hline & & 60 & 2,52 & 0,74 & 18,23 \\
\hline & \multirow{3}{*}{ Alkali } & 30 & 2,22 & 0,97 & 16,06 \\
\hline & & 45 & 2,41 & 0,94 & 17,44 \\
\hline & & 60 & 2,45 & 0,83 & 17,73 \\
\hline \multirow{6}{*}{ Hanjeli } & \multirow{3}{*}{$\begin{array}{c}\mathrm{pH} \\
\text { netral }\end{array}$} & 30 & 1,33 & 0,99 & 19,73 \\
\hline & & 45 & 1,60 & 0,95 & 23,73 \\
\hline & & 60 & 1,77 & 0,76 & 26,25 \\
\hline & \multirow{3}{*}{ Alkali } & 30 & 1,39 & 0,99 & 20,61 \\
\hline & & 45 & 1,76 & 0,96 & 26,10 \\
\hline & & 60 & 1,78 & 0,91 & 26,40 \\
\hline \multirow{6}{*}{ Jagung } & \multirow{3}{*}{$\begin{array}{c}\mathrm{pH} \\
\text { netral }\end{array}$} & 30 & 1,56 & 0,99 & 47,96 \\
\hline & & 45 & 1,66 & 0,97 & 51,03 \\
\hline & & 60 & 1,80 & 0,82 & 55,33 \\
\hline & \multirow{3}{*}{ Alkali } & 30 & 1,69 & 0,98 & 51,95 \\
\hline & & 45 & 1,70 & 0,97 & 52,26 \\
\hline & & 60 & 1,84 & 0,90 & 56,56 \\
\hline
\end{tabular}


Koefisien difusi (Deff) yang dihitung dari persamaan (5), berdasarkan pola perubahan kadar air yang terjadi selama perendaman. Nilai koefisien difusi yang meningkat seiring dengan peningkatan suhu perlakuan bermakna bahwa suhu perendaman mempercepat jumlah air yang masuk ke dalam bijian. Nilai koefisien difusi dalam penelitian ini berkisar $16,35 \times 10^{-12} \mathrm{~m}^{2} \mathrm{~s}^{-1}$ pada biji sorgum sampai dengan $56,56 \times 10^{-12} \mathrm{~m}^{2} \mathrm{~s}^{-1}$ pada biji jagung, sesuai dengan yang telah dilaporkan Foke \& Rathod (2013). Pada perlakuan perendaman menggunakan larutan alkali, terjadi peningkatan nilai koefisien difusi. Pengamatan ini sesuai dengan hasil yang dilaporkan Bello, Tolaba \& Suarez (2004) dan Snyder (1993), yang menunjukkan bahwa pH yang lebih tinggi akan mempercepat penyerapan air.

\section{Energi Aktivasi}

Interaksi antara koefisien difusi dan perubahan suhu dalam Persamaan Arrhenius (persamaan 6) digunakan untuk menghitung energi aktivasi. Persamaan umum Arrhenius merupakan persamaan yang dapat digunakan untuk menduga nilai koefisien difusi berdasarkan suhu mutlak proses perendaman. Plot antara nilai In Deff dengan $1 / T$ yaitu $1 /$ suhu mutlak perendaman akan menunjukkan sebuah grafik linear yang dapat digunakan untuk menghitung nilai energi aktivasi (Ea). Grafik hubungan nilai In Deff dengan $1 / T$ pada tiap-tiap perlakuan ditunjukkan pada Gambar 2.

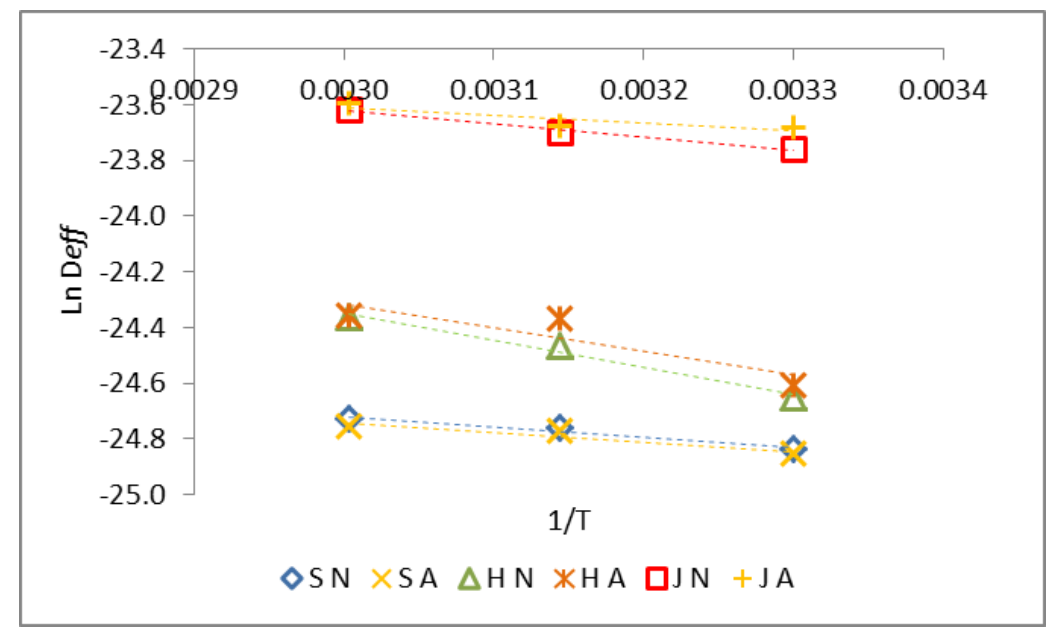

Gambar 2. Grafik hubungan Ln Deff dan 1/T

Gambar 2. menunjukkan grafik hubungan antara nilai Ln Deff dengan 1/T memiliki pola yang hampir sama pada setiap jenis biji. Dari setiap grafik akan diperoleh persamaan umum Arrhenius dari masing-masing jenis bijian. Dari persamaan Arrhenius, maka nilai energi aktivasi pada proses difusi air ke dalam biji sorgum, hanjeli, dan jagung selama perendaman dapat dihitung dan disajikan seperti Tabel 3. Nilai rata-rata koefisien determinasi yang sangat baik $\left(R^{2}>0,88\right)$ menunjukkan kesesuaian yang baik antara pendugaan koefisien difusi menggunakan persamaan Arrhenius dengan perhitungan dari data eksperimen yang diperoleh.
Energi aktivasi proses difusi pada biji sorgum, hanjeli, dan jagung memiliki nilai yang berbeda. Perbedaan yang terjadi menunjukkan bahwa karakteristik proses difusi bijian selama perendaman dipengaruhi oleh banyak faktor, baik terkait dengan sifat fisikokimia bijian maupun kondisi perendaman. Dari tabel 3. diketahui bahwa nilai energi aktivasi pada perendaman larutan alkali sebesar 2,78 kJ $\mathrm{mol}^{-1}$ untuk sorgum, $7,01 \mathrm{~kJ} \mathrm{~mol}^{-1}$ untuk hanjeli, dan 2,34 $\mathrm{kJ} \mathrm{mol}^{-1}$ untuk jagung. Nilai energi aktivasi tersebut lebih kecil dibandingkan perendaman biji sorgum, hanjeli, dan jagung pada larutan $\mathrm{pH}$ netral. Agarry, Afolabi \& Tunde-Akintunde (2014), meyatakan bahwa energi aktivasi yang 
semakin kecil menunjukkan koefisien difusi semakin besar. Nilai energi aktivasi yang lebih kecil pada perendaman alkali bermakna bahwa perendaman pada larutan alkali akan mempercepat proses difusi atau penyerapan air dalam bahan. Besarnya nilai energi aktivasi perendaman biji sorgum, jagung, dan hanjeli yang berkisar 2,34 - 8,02 $\mathrm{kJ} \mathrm{mol}^{-1}$ dalam penelitian ini selaras dengan apa yang sudah dilaporkan oleh Silva, Jorge, \& Jorge, (2018) untuk beberapa jenis bijibijian.

Tabel 3. Nilai energi aktivasi (Ea) dan persamaan umum Arrhenius

\begin{tabular}{|c|c|c|c|c|}
\hline$B i j i$ & Larutan & $\begin{array}{c}\mathrm{Ea} \\
\left(\mathrm{kJ} \mathrm{mol}^{-1}\right)\end{array}$ & Persamaan Arrhenius & $\mathbf{R}^{2}$ \\
\hline \multirow{2}{*}{ Sorgum } & $\begin{array}{c}\mathrm{pH} \\
\text { netral }\end{array}$ & 3,06 & $k=5,55 \times 10^{-11} \exp \left(\frac{-3,06 \mathrm{~kJ} / \mathrm{mol}}{R T}\right)$ & 0,96 \\
\hline & Alkali & 2,78 & $k=4,90 \times 10^{-11} \exp \left(\frac{-2,7 \mathrm{Rg} / \mathrm{mol}}{R T}\right)$ & 0,90 \\
\hline \multirow{2}{*}{ Hanjeli } & $\begin{array}{c}\mathrm{pH} \\
\text { netral }\end{array}$ & 8,02 & $k=4,82 \times 10^{-10} \exp \left(\frac{-8,02 \mathrm{~kJ} / \mathrm{mol}}{R T}\right)$ & 0,98 \\
\hline & Alkali & 7,01 & $k=3,44 \times 10^{-10} \exp \left(\frac{-7,01 \mathrm{~kJ} / \mathrm{mol}}{R T}\right)$ & 0,81 \\
\hline \multirow{2}{*}{ Jagung } & $\begin{array}{c}\mathrm{pH} \\
\text { netral }\end{array}$ & 3,99 & $k=2,33 \times 10^{-10} \exp \left(\frac{-3,99 \mathrm{~kJ} / \mathrm{mol}}{\mathrm{RT}}\right)$ & 0,99 \\
\hline & Alkali & 2,34 & $k=1,30 \times 10^{-10} \exp \left(\frac{-2.24 \mathrm{~kJ} / \mathrm{mol}}{R T}\right)$ & 0,79 \\
\hline
\end{tabular}

\section{KESIMPULAN}

Suhu yang lebih tinggi akan mempercepat laju penyerapan air dan meningkatkan difusivitas proses perendaman biji jagung, sorgum dan hanjeli. Perendaman pada larutan alkali dengan suhu $60{ }^{\circ} \mathrm{C}$ menghasilkan nilai kapasitas penyerapan maksimum tertinggi dan memiliki nilai energi aktivasi yang lebih kecil dibandingkan perendaman pada larutan $\mathrm{pH}$ netral. Persamaan Arrhenius memiliki akurasi sangat baik dalam pendugaan nilai difusi berdasarkan nilai energi aktivasi dan suhu mutlak perendaman. Dimungkinkan pelaksanaan penelitian lanjutan dengan perlakuan $\mathrm{pH}$ larutan perendaman pada beberapa level untuk mengetahui pengaruhnya terhadap proses difusi.

\section{UCAPAN TERIMA KASIH}

Ucapan terimakasih ditujukan kepada Universitas Lampung yang telah membiayai penelitian ini melalui skema Penelitian Dasar Tahun 2019.

\section{DAFTAR PUSTAKA}

Addo, A. dan A. Bart-Plange. 2009. Kinetics of water absorption by egusi melon (Cucumeropsis edulis) seeds. ARPN Journal of Agricultural and Biological Science. Vol. 4(6): 14-17.

Addo, A., Bart-Plange, A., and Dzisi, K. (2006). Water absorption characteristics of obatanpa and mamaba maize hybrids (Zea mays). International Journal of Food Engineering. Vol. 2(3): 15563758.

Agarry, S. E., T. J. Afolabi dan T. Y. TundeAkintunde. (2014). Modelling The Water Absorption Characteristics of Different Maize (Zea mays L.) Types During Soaking. Journal Food Processing and Technology. Vol. 5(5), 1-9. DOI: 10.4172/21577110.1000326

Asropi, Bintoro, N., Karyadi, J. N. W., Rahayoe, S., Saputro, A. D. (2019). Kinetika Perubahan Sifat Fisik dan Kadar Tanin Biji Sorgum (Sorghum bicolor L.) Selama Perendaman. Agritech. Vol. 39 (3): $222-233$

Bello, M., M.P. Tolaba dan C. Suarez. 2004. Factors Affecting Water Uptake of Rice Grain During Soaking. Lebensmittel-Wissenschaft undTechnologie. Vol. 37(8): 811-816. 
Badan Pusat Statistik. (2017). Konsumsi beras per kapita per minggu, Indonesia. htps://www.bps.go.id/statictable/2014/ 09/08/950/rata-rata-konsumsiperkapita-seminggu-beberapamacam-bahan-makanan-penting20072017.html. [20 Juli 2019].

Crank, J. (1975). The Mathematics of Diffusion Second Edition. Oxford University Press. Oxford. $411 \mathrm{pp}$.

Foke, V., and Rathod, D. (2013). Water diffusion co-efficient of paddy, rice, black gram and dhal. International Journal of Agricultural Engineering. Vol. 7(1), 125-130.

Ganguli, K. dan U. Ghosh. (2014). Application of Different Mathematical Models to Determine Hydration Characteristics of Paddy Grain. Bio Technology An Indian Journal. Vol. 10(24): 16471-16475.

Grubben, G.J.H., dan Partohardjono S. (Eds.) 1996. Plant Resources of South-East Asia No. 10 Cereals. Prosea. Bogor.

Karapantsios, T.D.; Sakonidou, E.P. and Raphaelides, S.N. (2002). Water dispersion kinetics during starch gelatinization. Carbohydrate Polymers 49(4), 479-490.

https://doi.org/10.1016/S01448617(02)00005-X

Kashiri, M., M. Kashaninejad dan N. Aghajani. (2010). Modeling Water Absorption of Sorghum During Soaking. Latin American Applied Research. Vol. 40(4), 383-388.

Peleg, M. (1988). An Empirical Model for The Description of Moisture Sorption Curve. Journal of Food Science. Vol. 53(4), 1216-1218. https://doi.org/10.1111/j.13652621.1988.tb13565.X

Seyhan-Gurtas, F.; Ak, M. M. and Evranuz, E. O. (2001). Water diffusion coefficients of selected legumes grown in Turkey as affected by temperature and variety. Turkish Journal of Agriculture. 25: 297-304

Silva, D.A.R.O. da, Jorge, L.M.M., Jorge, R.M.M. (2018). Kinetics study and modelling of sorghum grain hydration. Revista Ciência Agronômica, Vol. 50(1), 44-53.

http://dx.doi.org/10.5935/1806$\underline{6690.20190006}$

Snyder, E. B. (1993). Some Factors Affecting the Cooking Quality of the Pea and Great Northern Types of Dry Beans. Historical Research Bulletins of the
Nebraska Agricultural Experiment Station, (1936), 6-31.

Tagawa, A., Muramatsu, Y., Nagasuna, T., Yano, A., limoto, M., and Murata. S.(2003). Water absorption characteristics of wheat and barley during soaking. Transactions of the ASAE. 46(2): 361-366.

Tunde-Akintunde, T. Y. (2010). Water Absorption Characteristics of Nigerian Acha (Digitaria exilis). International Journal of Food Engineering, 6(5). https://doi.org/10.2202/1556$\underline{3758.1650}$ 